\title{
Factors Affecting the Etiology of Intractable Pruritus in Hospitalized Patients Without Primary Skin Lesions
}

\section{Yatırılarak Etiyolojik Araştırma Yapılan Primer Deri Lezyonu Olmayan Şiddetli Kaşıntılı Hastalarda Kaşıntı Etiyolojisini Etkileyen Faktörler}

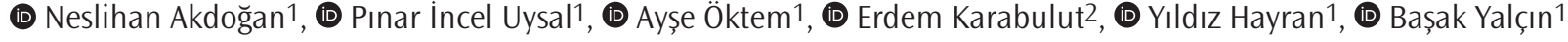 \\ 1University of Health Sciences, Ankara Numune Training and Research Hospital, Clinic of Dermatology and Venereology, Ankara, Turkey \\ 2Hacettepe University Faculty of Medicine, Department of Biostatistics, Ankara, Turkey
}

\begin{abstract}
Introduction: Pruritus is a common symptom that has dermatologic, systemic, neurological, psychogenic, mixed, and unknown causes. The aim of this study was to identify the underlying origin of pruritus (UOP) in hospitalized patients having intractable pruritus and presenting with secondary scratch lesions (SSLS) and to assess the factors affecting UOP.

Methods: Data of 95 patients (male/female: 47/48) presenting with SSLS were examined retrospectively. Demographic and clinical characteristics, diagnostic procedures, and treatment agents were recorded. UOP was defined as dermatological and non-dermatological factors.

Results: The median (range) age and disease duration were 61 years (11-91) and 2 months (0.06-120), respectively. Pruritus was related to dermatological and non-dermatological reasons in $78 \%$ and $22 \%$ of patients. Univariate analysis revealed that factors showing an association between patients with and without underlying dermatological origin of [pruritus (UDOP)] were age, disease duration, disease onset, $\geq 3$ months of continuous drug use, intake of drugs attributed to lead to pruritus, accompanying systemic diseases, polypharmacy, renal function tests, and the presence of sleep disorders $(p=0.001, p=0.001, p=0.001, p=0.03, p=0.045, p=0.02$, $p=0.004, p=0.047$ and $p=0.01$, respectively). Multivariate analyses revealed that acute onset of pruritus increased the risk of UDOP by 15.28 times ( $p=0.005,95 \%$ confidence interval (CI): 2.30-101.67) compared to patients with chronic onset. The lack of sleep disorders increased the risk of UDOP by 8.22 times ( $p=0.01,95 \% \mathrm{Cl}: 1.67-40.56)$ compared to patients who had sleep disorders.
\end{abstract}

Conclusion: Acute onset of pruritus and lack of sleep disorders were independent predictors of UDOP in patients with SSLS. The remaining patients without UDOP should be directed to the relevant departments for accurate diagnosis and management.

Keywords: Pruritus, etiology, skin

\section{öz}

Amaç: Kașıntı sık görülen bir belirti olup dermatolojik, sistemik, nörolojik, psikojenik, mikst ve bilinmeyen sebepleri vardır. Bu çalışmanın amacı sekonder deri lezyonları (SDL) ile prezente olan, dirençli kaşıntı nedeniyle hastanede yatan hastalarda kașıntı etiyolojisini (KET) bulmak ve KET’i etkileyen faktörleri değerlendirmektedir.

Yöntemler: Retrospektif olarak SDL olan 95 hasta (erkek/ kadın: 47/48) çalışmaya alındı. Demografik ve klinik özellikler, tanısal işlemler ve tedavi ajanları kaydedildi. KET dermatolojik ve dermatoloji dışı sebepler olarak tanımlandı.

Bulgular: Çalıșmamızda ortalama (aralık) yaş 61 (11-91) yıl ve hastalık süresi $2(0,06-120)$ aydı. Kașıntı \%78 hastada dermatolojik, \%22 hastada dermatoloji dışı sebeplerle ilişkili bulundu. Tek değişkenli analiz yaş, ortalama hastalık süresi, akut veya kronik seyir, 3 aydan uzun süre sürekli ilaç kullanımı, kaşıntıya yol açabilecek ilaç kullanımı, eşlik eden sistemik hastalık, polifarmasi, böbrek fonksiyon testleri ve uyku bozukluğu varlığı ile altta yatan dermatolojik sebebe bağlı kaşıntısı (DSK) olan ve olmayan hastalarda ilişki gösterdi (sırasıyla $p=0,001, p=0,001, p=0,001, p=0,03, \quad p=0,045$, $p=0,02, p=0,004, p=0,047$ ve $p=0,01$ ). Çok değişkenli analiz kronik kaşıntısı olan hastalarla karşılaştıııldığında akut kaşıntıSı olan hastalarda DSK riskinin 15,28 kat ( $p=0,005$, 95\% CI): 2.30-101,67) arttığını gösterdi. Uyku bozukluğu olan hastalarla karşılaştırıldığında uyku bozukluğu yokluğunun DSK riskini 8,22 kat ( $p=0,01,95 \% \mathrm{Cl}: 1,67-40,56)$ artırdığı görüldü.

Sonuç: Kaşıntının akut seyirli olması ve uyku bozukluğunun olmaması SDL olan kaşıntılı hastalarda DSK'nin bağımsız prediktörleridir. DSK olmayan hastalar tanı ve tedavi için uygun bölümlere yönlendirilmelidir.

Anahtar Kelimeler: Kașıntı, etiyoloji, deri
Address for Correspondence/Yazıșma Adresi: Neslihan Akdoğan MD, University of Health Sciences, Ankara Numune Training and Research Hospital, Clinic of Dermatology and Venereology, Ankara, Turkey Phone: +90 3125085643 E-mail: nslakdogan@gmail.com ORCID ID: orcid.org/0000-0002-1137-5399

Cite this article as/Atıf: Akdoğan N, Incel Uysal P, Öktem A, Karabulut E, Hayran Y, Yalçın B. Factors Affecting the Etiology of Intractable Pruritus in Hospitalized Patients Without Primary Skin Lesions. İstanbul Med J 2019; 20(3): 224-30.

(c) Copyright 2019 by the Istanbul Training and Research Hospital/Istanbul Medical Journal published by Galenos Publishing House.

(C) Telif Hakkı 2019 Istanbul Ĕgitim ve Araștırma Hastanesi/Istanbul Tıp Dergisi, Galenos Yayınevi tarafından basılmıștır.
Received/Geliș Tarihi: 19.07.2018 Accepted/Kabul Tarihi: 13.12.2018 


\section{Introduction}

Pruritus is described as a sensation that will provoke scratching or the desire to scratch (1). It is defined either acute or chronic. Chronic form was described by the International Forum for the Study of Itch in 2007 as that lasting 6 or more weeks (2). Pruritic patients are divided into 6 groups according to the underlying etiologies such as dermatologic, systemic, neurologic, psychogenic/psychosomatic, mixed and other reasons (2). Well-known dermatologic conditions associated with pruritus are inflammatory skin diseases, infectious dermatoses, neoplastic conditions, genodermatoses, autoimmune bullous diseases, and some pregnancy dermatoses (3).

The underlying etiologies of patients with pruritus are sometimes detected easily. However, the exact diagnosis remains challenging when patients only present with secondary scratch lesions (SSLS) instead of presentation with primary skin lesions (PSLs) (4). Some patients may only present with SSLs without any PSLS. However, SSLS may arise from the manipulation of PSLs or from external forces such as scratching, trauma in the absence of PSLs. In accordance with the findings outlined above, it may not be possible to reach the underlying origin of pruritus (UOP) in patients with SSLS. Hence, the aim of the study was to identify the UOP and to assess the factors affecting UOP in hospitalized patients with intractable pruritus in the absence of PSLS.

\section{Methods}

Data of the patients with the diagnosis of pruritus of unknown etiology defined by the ICD-10 codes L29 (pruritus), L29.8 (other pruritus), L29.9 (pruritus, not elsewhere classified), and L28.2 (other prurigo) were retrospectively collected from hospital databases between October 2013 and November 2016. Regardless of the duration of pruritus, patients with acute or chronic onset and intractable pruritus were enrolled. Intractable pruritus is defined to be refractory to conventional therapies for pruritus (combination of oral antihistamines, topical mild or moderate potent corticosteroid ointments and moisturizers) given at least for 2 months and/or generalized distribution in patients for whom topical therapies were not appropriate and/or intense pruritus leading sleep disorders, disturbance of daily activities. Pruritic patients with underlying dermatoses were excluded. In all patients presented with SSLs in the absence of identifiable PSLS. SSLS were described as excoriation, lichenification, fissure, erosion, ulceration, scale, and crust.

Demographic data including age, gender, duration of pruritus, personal and familial medical history, onset of disease (acute/chronic), and previous and current topical and systemic treatment agents were recorded. Patients were questioned for sleep disorders due to pruritus. The presence of xerosis was checked. Patients were classified by age groups according to the World Health Organization's old age description ( $<60$ years and $>60$ years) for statistical analysis (5). The duration of pruritus was expressed in months. A detailed medication (use of any drug due to a reason other than pruritus) history including $\geq 3$ months of continuous drug use and newly initiated drug therapy in the past 30 days was obtained. Polypharmacy was defined as the concurrent use of $\geq 4$ drugs. The European guideline was used to detect potential drugs that could lead to pruritus (6).
Collected laboratory investigation data comprised of serum levels of liver transaminases, renal function tests, blood eosinophil cell count, total serum immunoglobulin E (IgE) levels, and stool parasite tests. Eosinophilia was described as a peripheral blood eosinophil cell count $>600$ cells/microliter. The extent of eosinophilia was classified into 3 groups as mild (600-1500 cells/mL), moderate (1500-5000 cells $/ \mathrm{mL})$ or severe $(>5000$ cells $/ \mathrm{mL})$. A serum total IgE level $>87 \mathrm{IU} / \mathrm{mL}$ was considered high. Stool specimens were collected over a 3-day period. Number of patients undergoing testing for malignant disease and testing for skin biopsy, lymph node biopsy, patch test or any other invasive diagnostic procedures were recorded. Numbers and details of the radiological studies and invasive diagnostic tests were based on the patients' first hospitalization for pruritus prior to the initiation of treatments. The result of skin biopsies was reviewed. The status of direct immunofluorescence microscopy (DIF) was questioned.

The number and content of consultations requested during hospitalization were examined. The duration of hospitalization was expressed in days. The diagnoses were confirmed by clinical features and histopathological findings. Patients were then classified according to the UOP such as dermatological and non-dermatological factors. The associations between patients with and without underlying dermatological origin of pruritus (UDOP) were assessed.

\section{Statistical Analysis}

All statistical analyses were performed using the software of Statistical Package for the Social Sciences (SPSS, Inc., Chicago, IL, USA) version 20.0. Demographic and clinical characteristics of the study population were analyzed using descriptive statistics. All numeric variables were expressed as median (range) since no numeric variables followed normality in this study. Categorical variables were described by frequency and percentage. Differences in numeric variables between patients with and without UDOP were analyzed by using the Mann-Whitney $U$ test. The chi-square test $\left(\left(\chi^{2}\right)\right.$ was employed to determine whether there were differences in categorical variables between independent groups. Multivariate logistic regression analysis was used to analyze variables with $p$ value cut-off point of 0.15 via following elimination of confounding factors. The strength of the association between variables and UOP was assessed by odds ratios (ORs) with the corresponding 95\% confidence intervals (Cls). A $p$ value of $<0.05$ was accepted statistically significant.

The study was approved by the Ankara Numune Training and Research Hospital Ethics Committee (decision no: E-16-1065, 19 October 2016). All procedures performed in the study were in accordance with the ethical principles of the 1964 Helsinki Declaration. Due to the retrospective design, patient consent was not obtained.

\section{Results}

\section{Demographic and Clinical Characteristics of the Study Population}

The study included 95 participants, including 47 males and 48 females who were examined by the consultant dermatologists. The median (range) age and disease duration was 61 years (11-91) and 2 months (0.06-120 months), respectively. The distribution of patients according to demographic and clinical characteristics, laboratory parameters, 


\begin{tabular}{|c|c|}
\hline Data & Patient group, $\mathrm{n}(\%)$ \\
\hline Age, years, median (range) & $61(11-91)$ \\
\hline \multicolumn{2}{|l|}{ Age distribution (years) } \\
\hline$<60$ years & $47(49.5 \%)$ \\
\hline$>60$ years & $48(50.5 \%)$ \\
\hline \multicolumn{2}{|l|}{ Gender } \\
\hline Male & $47(49.5 \%)$ \\
\hline Female & $48(50.5 \%)$ \\
\hline Disease duration, months, median (range) & $2(0.06-120)$ \\
\hline \multicolumn{2}{|l|}{ Disease onset } \\
\hline Acute & $40(42 \%)$ \\
\hline Chronic & $55(58 \%)$ \\
\hline \multicolumn{2}{|l|}{ Intake of drugs } \\
\hline$\geq 3$ months of continuous drug use & $53(56 \%)$ \\
\hline Newly initiated drug therapy in the past 30 days & $8(8 \%)$ \\
\hline Polypharmacy & $26(27 \%)$ \\
\hline \multicolumn{2}{|l|}{ Laboratory results } \\
\hline Abnormal liver transaminases & $8(8 \%)$ \\
\hline Abnormal renal function tests & $11(12 \%)$ \\
\hline Eosinophilia & $29(31 \%)$ \\
\hline Elevated serum total IgE levels & $17(18 \%)$ \\
\hline Negative stool parasite test & $38(40 \%)$ \\
\hline Positive stool parasite test & $1(1 \%)$ \\
\hline Unknown stool parasite test & $56(59 \%)$ \\
\hline \multicolumn{2}{|l|}{ Radiological investigations } \\
\hline Chest x-ray & $73(77 \%)$ \\
\hline Computerized tomography & $15(16 \%)$ \\
\hline Magnetic resonance imaging & $1(1 \%)$ \\
\hline Ultrasonography of superficial lymph nodes & $19(20 \%)$ \\
\hline Ultrasonography of abdomen & $60(63 \%)$ \\
\hline Others & $21(22 \%)$ \\
\hline \multicolumn{2}{|l|}{ Diagnostic invasive procedures } \\
\hline Skin biopsy & $73(77 \%)$ \\
\hline Lymph node biopsy & $2(2 \%)$ \\
\hline Patch test & $1(1 \%)$ \\
\hline Others & $7(7 \%)$ \\
\hline \multicolumn{2}{|l|}{ Previous medications } \\
\hline Topical corticosteroids & $45(47 \%)$ \\
\hline Moisturizers & $24(25 \%)$ \\
\hline Topical antihistamines & $3(3 \%)$ \\
\hline Oral antihistamines & $60(63 \%)$ \\
\hline Systemic corticosteroids & $21(22 \%)$ \\
\hline Permethrin cream & $9(10 \%)$ \\
\hline Topical antifungals & $4(4 \%)$ \\
\hline Oral antifungals & $5(5 \%)$ \\
\hline Topical antibiotics & $8(8 \%)$ \\
\hline Oral antibiotics & $5(5 \%)$ \\
\hline
\end{tabular}

\section{Table 1 contiuned}

\begin{tabular}{|l|l|}
\hline Oral cyclosporine & $1(1 \%)$ \\
\hline Oral acitretin & $1(2 \%)$ \\
\hline Azatiopurine & $1(1 \%)$ \\
\hline Narrow-band UVB & $3(3 \%)$ \\
\hline Omalizumab & $1(1 \%)$ \\
\hline Gabapentin & $1(1 \%)$ \\
\hline Untreated or unknown & $15(16 \%)$ \\
\hline Current treatment options & \\
\hline Topical corticosteroids & $75(79 \%)$ \\
\hline Moisturizers & $49(52 \%)$ \\
\hline Oral antihistamines & $79(83 \%)$ \\
\hline Systemic corticosteroids & $37(39 \%)$ \\
\hline Permethrin cream & $8(8 \%)$ \\
\hline Topical antifungals & $2(2 \%)$ \\
\hline Oral antifungals & $1(1 \%)$ \\
\hline Topical antibiotics & $15(16 \%)$ \\
\hline Oral cyclosporine & $4(4 \%)$ \\
\hline Oral acitretin & $1(1 \%)$ \\
\hline Azatiopurine & $1(1 \%)$ \\
\hline Narrow-band UVB & $4(4 \%)$ \\
\hline Omalizumab & $1(1 \%)$ \\
\hline Gabapentin & $15(16 \%)$ \\
\hline Antidepressants & $15(16 \%)$ \\
\hline Oral antibiotics & $6(6 \%)$ \\
\hline Dapsone & $2(2 \%)$ \\
\hline Wound care & $2(2 \%)$ \\
\hline n: number; UVB: Ultraviolet B phototherapy & \\
\hline
\end{tabular}

Table 2. Frequency of accompanying diseases in this study Diseases

Diabetes mellitus

Hypertension

Cardiovascular diseases

Cardiac failure or arrhythmia

Pulmonary diseases

Renal diseases

Hypothyroidism

Neuropsychiatric diseases

Iron deficiency anemia

History of solid tumor

Others (gastritis, benign prostatic hyperplasia,

cataracts, allergic rhinitis, adrenal insufficiency,

rheumatoid arthritis, sarcoidosis, hemorrhoid, vitiligo, polymyalgia rheumatica)

*More than one systemic disease was seen in some patients

$\mathrm{n}$ : number, \%: percentage

radiological investigations, diagnostic invasive tests, and previous and current treatment agents are shown in Table 1. Table 2 shows the frequency of accompanying diseases in this study. 
Of all, 55 of 95 (58\%) patients were using at least one drug for a reason other than pruritus since admission to the hospital. Besides, 45 of these 55 (82\%) patients were using a drug which might induce pruritus. Although 22 of these 45 (49\%) patients underwent withdrawal or change of the suspected drugs that was associated with pruritus, only 3 patients achieved complete remission of pruritus after drug cessation.

Of 95 patients, 24 (25\%) patients exhibited xerosis, whereas 12 patients (13\%) suffered from sleep disorders. All patients received at least one consultation during the hospitalization, mostly from internal medicine,

\begin{tabular}{|c|c|}
\hline Diseases underlying pruritus & $\mathrm{n}=95(\%)$ \\
\hline Dermatological origin of pruritus & $\mathrm{n}=74(78 \%)$ \\
\hline Contact dermatitis & 23 \\
\hline Drug reactions & 18 \\
\hline Other inflammatory dermatoses & 17 \\
\hline Autoimmune bullous diseases & 8 \\
\hline Pregnancy dermatoses & 3 \\
\hline Cutaneous lymphomas & 2 \\
\hline Infectious dermatoses & 3 \\
\hline Non-dermatological origin of pruritus & $n=21(22 \%)$ \\
\hline Psychogenic origin of pruritus & 8 \\
\hline Neurogenic origin of pruritus & 3 \\
\hline \multicolumn{2}{|l|}{ Systemic origin of pruritus } \\
\hline Drug-induced pruritus & 2 \\
\hline Infection-induced pruritus & 1 \\
\hline \multicolumn{2}{|l|}{ Mixed } \\
\hline Psychogenic and neurogenic origin & 4 \\
\hline Drug and infection induced pruritus & 1 \\
\hline \multicolumn{2}{|l|}{ Pruritus of unknown origin } \\
\hline Prurigo simplex & 2 \\
\hline
\end{tabular}

Table 4. Comparisons of numeric variables between patients with and without underlying dermatological origin of pruritus by univariate analysis

\begin{tabular}{|l|l|l|l|}
\hline Variable & $\begin{array}{l}\text { Patients with } \\
\text { UDOP median } \\
\text { (range) }\end{array}$ & $\begin{array}{l}\text { Patients } \\
\text { without UDOP } \\
\text { median (range) }\end{array}$ & $\mathbf{p}$ \\
\hline Age & $56(11-91)$ & $73(40-88)$ & 0.001 \\
\hline Duration of pruritus & $1(0.06-120)$ & $7(0.130-120)$ & 0.001 \\
\hline Blood eosinophil count & $350(0-5400)$ & $300(100-1000)$ & 0.34 \\
\hline Duration of hospitalization & $8(1-37)$ & $7(2-16)$ & 0.32 \\
\hline $\begin{array}{l}\text { P values <0.05 is shown in bold } \\
\text { UDOP: Underlying dermatological origin of pruritus }\end{array}$ & & \\
\hline
\end{tabular}

psychiatry and ophthalmology (median: 1, range: 0-9). The median duration of hospitalization was 8 days (range:1-34).

\section{Diseases Underlying Intractable Pruritus}

A definitive diagnosis was confirmed by histopathological examination in 53 of 95 (56\%) patients. The initial diagnoses by the dermatologist for the biopsy included allergic contact dermatitis (CD) $(n=9)$, drug eruption $(n=7)$, bullous pemphigoid $(n=6)$, mycosis fungoides $(n=5)$, cutaneous vasculitis $(n=4)$, lichen planus $(n=3)$, dermatitis herpetiformis $(n=3)$, urticaria $(n=3)$, psoriasis $(n=2)$, lichenoid drug eruption $(n=2)$, pemphigoid gestationis $(n=2)$, actinic reticuloid $(n=2)$, pityriasis rosea $(n=1)$, Grover's disease $(n=1)$, eosinophilic cellulitis $(n=1)$, pemphigus vulgaris $(n=1)$, and impetigo $(n=1)$. However, detailed history, clinical and histopathological findings, and treatment responses led us to conclude on certain diagnosis in 42 of 95 (44\%) patients who did not have definitive histopathological diagnoses. Intractable pruritus was associated with dermatological reasons in 74 of 95 (78\%) patients and with non-dermatological reasons in 21 of 95 (22\%) patients. The extended examination of all patients according to UOP is shown in Table 3.

The Mann-Whitney $U$ test showed that, for patients with UDOP vs without UDOP, the median age and median disease duration were 56 (11-91) vs 73 (40-88) and $1(0.06-120)$ vs 7 (0.13-120), respectively $(p=0.001$ and $p=0.001$, respectively) (Table 4). There was no difference between patients with UDOP and without UDOP in terms of the median eosinophil count and duration of hospitalization $(p=0.34$ and $p=0.32$, respectively).

$\chi^{2}$ test revealed that there was an association between patients with and without UDOP, and disease onset, $\geq 3$ months of continuous drug use, polypharmacy, intake of drugs attributed to lead to pruritus, accompanying systemic diseases, renal function tests and sleep disorders $(p=0.001, p=0.03, p=0.004, p=0.045, p=0.02, p=0.047$ and $p=0.01$, respectively). Univariate analysis showed that there was not any significant association between patients with and without UDOP, and gender, xerosis, eosinophilia, liver transaminases, and use of a drug initiated in the last 30 days (Table 5).

Multivariate logistic regression analyses revealed that no parameter was significantly associated with UOP, except disease onset and sleep disorders. Furthermore, acute onset of pruritus increased the risk of UDOP by 15.28 times ( $p=0.005,95 \% \mathrm{Cl}: 2.30-101.67)$ compared to chronic onset. The lack of sleep disorders increased the risk of UDOP by 8.22 -fold ( $p=0.01,95 \% \mathrm{Cl}: 1.67-40.56$ ) compared to patients who had sleep disorders. Therefore, acute pruritus onset and lack of sleep disorders were significant independent predictors of UOP in patients with intractable pruritus in this study (Table 6).

\section{Discussion}

Pruritus is one of the most frequent symptoms in many diseases. It can be associated with dermatological, systemic, neurological, and psychiatric diseases, however, its underlying etiology cannot be found in some patients despite detailed investigations (2). In our study, $78 \%$ of patients had a dermatological disease, whereas a dermatological origin was 
Table 5. Associations between patients with and without underlying dermatological origin of pruritus and parameters

\begin{tabular}{|c|c|c|c|}
\hline Characteristic & $\begin{array}{l}\text { Patients with } \\
\text { UDOP } \%(n=74)\end{array}$ & $\begin{array}{l}\text { Patients without } \\
\text { UDOP } \%(n=21)\end{array}$ & $p$ \\
\hline Age & & & 0.002 \\
\hline$<60$ years & $58 \%(n=43)$ & $19 \%(n=4)$ & \\
\hline$>60$ years & $42 \%(n=31)$ & $81 \%(n=17)$ & \\
\hline \multicolumn{4}{|l|}{ Gender } \\
\hline Female & $46 \%(n=34)$ & $67 \%(n=14)$ & 0.09 \\
\hline Male & $54 \%(n=40)$ & $33 \%(n=7)$ & \\
\hline Onset & & & 0.001 \\
\hline Acute & $51 \%(n=38)$ & $10 \%(n=2)$ & \\
\hline Chronic & $49 \%(n=36)$ & $90 \%(n=19)$ & \\
\hline $\begin{array}{l}\geq 3 \text { months of } \\
\text { continuous drug } \\
\text { use }\end{array}$ & & & 0.03 \\
\hline Yes & $50 \%(n=37)$ & $76 \%(n=16)$ & \\
\hline No & $50 \%(n=37)$ & $24 \%(n=5)$ & \\
\hline Polypharmacy & & & 0.004 \\
\hline Yes & $20 \%(n=15)$ & $52 \%(n=11)$ & \\
\hline No & $80 \%(n=59)$ & $48 \%(n=10)$ & \\
\hline $\begin{array}{l}\text { Use of drug } \\
\text { initiated in the last } \\
30 \text { days }\end{array}$ & & & 0.12 \\
\hline Yes & $11 \%(n=8)$ & $0 \%(n=0)$ & \\
\hline No & $89 \%(n=66)$ & $100 \%(n=21)$ & \\
\hline $\begin{array}{l}\text { Drugs attributed to } \\
\text { cause pruritus }\end{array}$ & & & 0.045 \\
\hline Yes & $42 \%(n=31)$ & $67 \%(n=14)$ & \\
\hline No & $58 \%(n=43)$ & $33 \%(n=7)$ & \\
\hline Eosinophilia & & & 0.07 \\
\hline Present & $35 \%(n=26)$ & $14 \%(n=3)$ & \\
\hline Absent & $65 \%(n=48)$ & $86 \%(n=18)$ & \\
\hline $\begin{array}{l}\text { Abnormal liver } \\
\text { transaminases }\end{array}$ & & & 0.49 \\
\hline Present & $10 \%(n=7)$ & $5 \%(n=1)$ & \\
\hline Absent & $90 \%(n=67)$ & $95 \%(n=20)$ & \\
\hline $\begin{array}{l}\text { Abnormal renal } \\
\text { function tests }\end{array}$ & & & 0.047 \\
\hline Yes & $8 \%(n=6)$ & $24 \%(n=5)$ & \\
\hline No & $92 \%(n=68)$ & $76 \%(n=16)$ & \\
\hline $\begin{array}{l}\text { Accompanying } \\
\text { systemic diseases }\end{array}$ & & & 0.02 \\
\hline Present & $65 \%(n=48)$ & $91 \%(n=19)$ & \\
\hline Absent & $35 \%(n=26)$ & $9 \%(n=2)$ & \\
\hline Sleep disorders & & & 0.01 \\
\hline Present & $8 \%(n=6)$ & $29 \%(n=6)$ & \\
\hline Absent & $92 \%(n=68)$ & $71 \%(n=15)$ & \\
\hline Xerosis & & & 0.10 \\
\hline Present & $24 \%(n=18)$ & $29 \%(n=6)$ & \\
\hline Absent & $5 \%(n=4)$ & $19 \%(n=4)$ & \\
\hline Not known & $71 \%(n=52)$ & $52 \%(n=11)$ & \\
\hline \multicolumn{4}{|c|}{$\begin{array}{l}\text { P values }<0.05 \text { is shown in bold. Chi-square test was used to make comparisons between } \\
\text { the relevant groups }\end{array}$} \\
\hline UDOP: Underlying derm & ological origin of pr & & \\
\hline
\end{tabular}

Table 6. Multivariate logistic regression analysis for variables in patients with and without underlying dermatological origin of pruritus after the elimination of confounding factors

\begin{tabular}{|l|l|l|}
\hline Variable & $\mathbf{p}$ & $\mathbf{O R}(\mathbf{9 5} \% \mathbf{C I})$ \\
\hline Disease onset & $\mathbf{0 . 0 0 5}$ & - \\
\hline Acute & - & $15.28(2.30-101.67)$ \\
\hline Chronic & - & $1($ ref $)$ \\
\hline Sleep disorders & $\mathbf{0 . 0 1}$ & - \\
\hline Yes & - & $1($ ref $)$ \\
\hline No & - & $8.22(1.67-40.56)$ \\
\hline OR: odds ratios, Cl: confidence interval & \\
\hline
\end{tabular}

not specified in the remaining $22 \%$ who had psychogenic, neurogenic, systemic, mixed, and unknown etiologies. Additionally, disease onset and the status of sleep disorders were significant independent predictors of UOP in patients with SSLs. The conduction of the present study in the dermatology unit of a tertiary hospital in a metropolitan region may lead to the detection of a high rate of dermatological disease in the absence of PSLs.

The most common disease associated with intractable pruritus was contact dermatitis in this study. Although allergic (A) CD is less common than irritant $C D, A C D$ may be presented with a generalized distribution and intense pruritus due to its being an immune-mediated reaction (7). Thus, ACD should be suspected and evaluated in patients with pruritic eruptions.

Drug eruptions were the second common etiology associated with intractable pruritus following CD in this study. Drugs may lead to pruritus in the form of drug eruptions as a dermatological etiology or in the form of drug-induced pruritus acting as a non-dermatological etiology (6). Eighteen of 95 patients (19\%) were suffering from drug eruptions, whereas 3 of 95 patients (3\%) were attributed to have drug-induced pruritus that was diagnosed by the disappearance of pruritus after the cessation of the suspected drug in this study. Univariate analysis revealed that there was a significant association between patients with and without UDOP and $\geq 3$ months of continuous drug use, intake of drugs attributed to lead to pruritus, and polypharmacy. However, there was no significant relationship between patients with UDOP and without UDOP and use of a drug initiated in the past 30 days. Therefore, one can speculate that drugs may affect the UOP if a patient is in $\geq 3$ months of drug use, has polypharmacy or is taking any drugs attributed to lead to pruritus. Otherwise, drugs did not seem to affect the etiology of pruritus in patients who were in $<1$ month of drug use. Clinicians should take a detailed history of drug usage with its time of onset and total duration of use and should not forget that drugs may lead to pruritus without PSLs both in the forms of drug eruptions and in drug-induced pruritus. A recent guideline proposes that the suspected drug should be stopped if risk vs benefit analysis is reasonable to the patient and clinician with regards to drug-induced pruritus (8). Thus, dermatologists should be aware of potential differences in the clinical presentation, diagnostic approaches, and management of drug-associated pruritus forms. However, after the elimination of confounding factors, drug use did not have any effects on UOP in patients with SSLs in this study. 
Apart from CD and drug reactions, other inflammatory dermatoses, detected in 17 patients, were the third most common UDOP in this study, which comprised of atopic dermatitis, urticaria, perforating dermatosis, urticarial and leukocytoclastic vasculitis. Indeed, the clinical appearance may have been changed or masked with the disappearance or camouflage of PSLs due to intense itching in these inflammatory dermatoses. Furthermore, patients may present with intractable pruritus in the pre-bullous phase of bullous pemphigoid and in dermatitis herpetiformis without PSLs, as in 8 patients in this study $(9,10)$.

Besides dermatological etiologies, systemic diseases, neurological disorders and psychosomatic/psychiatric diseases are attributed to lead to pruritus $(2,11)$. Several systemic diseases including iron deficiency anemia, hepatobiliary diseases, polycythemia vera, neoplasms and endocrine disorders have been reported to be especially associated with the chronic form of pruritus in the literature (12). Systemic etiologies were detected in 4 of 95 patients (4\%) (one patient in the form of infection-induced, 3 patients in the form of drug-induced pruritus), suggesting that systemic diseases that were potentially associated with pruritus were relatively infrequent in our study population. However, it is not possible to ignore the impact of detected systemic diseases, such as diabetes mellitus, iron deficiency anemia, hypothyroidism, renal failure, on pruritus in patients with SSLS. Accordingly, univariate analysis showed that there was a significant association between patients with and without UDOP and accompanying systemic diseases. Systemic diseases showing relationship with pruritus may have contributed to the development of pruritus instead of its being primary reason. Additional research is needed to further clarify the exact role of accompanying diseases in the development of pruritus, and clinical significance, so as to discern if this knowledge can improve our attitude in intractable pruritus.

Psychogenic and neurogenic etiologies were considered in 15 of 95 patients (16\%) in this study. It is known that psychiatric diseases may cause an increased response of the peripheral and central nervous system to pruritogenic stimuli, whereas neurogenic diseases may lead to hyperstimulation via pruritogens at the nerve fiber $(13,14)$. To provide proper treatments, it is important to evaluate the psychogenic burden of pruritus when examining a patient with intractable and chronic pruritus. Hypo or hyperesthesia, symptoms of pain, and localized or generalized distribution may differentiate neurogenic form of pruritus in cases from other subgroups (13). It should not be forgotten that drugs may sometimes be more frequently associated with pruritus than the systemic diseases for which they are used. For example, topiramate may improve psychogenic pruritus, which also induced drug-induced pruritus (15).

Despite detailed investigations, UOP was not identified in 2 of 95 (2\%) patients diagnosed with prurigo simplex through histopathology. Both of the two patients presented with chronic pruritus and were older than 60 years. Ständer et al. (2) proposed to classify this group as "others" and called them as "pruritus of undetermined origin" particularly in patients with chronic condition. Warlich et al. (16) showed that 32 of 510 (6.3\%) patients with chronic pruritus were categorized into the group with unknown etiology. The present study demonstrated lower frequency of patients with unknown etiology compared to existing literature. If this study had included only patients with chronic onset and older ages, a higher rate of patients with unknown etiology might have been found. Additionally, the fact that patients may have been actually hospitalized to investigate the UOP might have diminished the number of unknown cases.

Although univariate analysis showed that there was no significant association between patients with and without UDOP, and xerosis, the contribution of xerosis to pruritus should not be overlooked in patients especially with chronic pruritus in the presence of SSLS. While pruritus is a common symptom in the elderly population, xerosis is the most frequent dermatological change leading to pruritus in this group (17). In the present study, 24 of 95 patients (25\%), 11 of whom were elderly patients, had dry skin, whereas the status of xerosis was not known in 63 of 95 patients. Therefore, it would be appropriate to make certain comments on the impact of xerosis for the prediction of UOP in patients with SSLS.

According to the present study, for the acute onset of pruritus, it is more likely to find an etiology of dermatological origin for intractable pruritus in the absence of PSLS. A cross-sectional study showed that no difference was found between patients with acute and chronic pruritus in terms of the distribution of diagnoses and sleeplessness due to pruritus (18).

Pruritus is an unpleasant symptom that can negatively affect quality of life, and cause mood disturbances and disarranged sleep patterns in many patients. In this study, 12 of 95 patients (13\%), for whom psychiatry consultation was requested, were suffering from sleep disorders due to pruritus. Oral antidepressant therapy was initiated in 7 of these 12 patients by the psychiatry department. Since oral antidepressants were considered to have antipruritic effects through their influence on serotonin and histamine levels, they were suggested for patients with chronic pruritus who gave no respond to other treatments (19). Univariate and multivariate analyses showed that there was a significant association between patients with and without UDOP, and sleep disorders. The lack of sleep disorders increased the risk of UDOP by 8.22 -fold ( $p=0.01,95 \% \mathrm{Cl}$ : $1.67-40.56$ ) compared to patients having sleep disorders. Therefore, the presence of sleep disorders may have effects on UOP in patients with SSLS. Zachariae et al. (20) used an adapted form of Itch Severity scale in their study and demonstrated that the severity of pruritus was significantly correlated with impaired sleep quality among different origins of pruritus. Furthermore, the impact of several dermatoses including atopic dermatitis (21), psoriasis (22), chronic urticaria (23), and autoimmune bullous diseases (24) on sleep quality should not be ignored. Indeed, it should not be forgotten that patients with intractable pruritus may have impaired sleep quality in variable degrees regardless of the onset of pruritus.

The main limitations of this study were the retrospective design and the dependence of medical records of patients on hospital-based information. The absence of stool parasite examination in a large number of patients, the obscurity of previous medications in some patients, the lack of certain histopathological diagnoses in all biopsied cases are the other limitations for this study. Additionally, causality could not be evaluated due to its retrospective design. However, we think that our study contributes to the existing literature. It should not be forgotten 
that besides dermatological reasons, intractable pruritus in the absence of PSLs may be associated with systemic reasons such as drugs and infections as well as psychogenic, neurogenic, mixed and unknown reasons. So, patients with intractable pruritus should be directed to the relevant departments for accurate diagnosis and correct treatment. Additionally, the onset of acute pruritus and lack of sleep disorders were significant independent predictors of UDOP in patients with SSLS. Further prospective investigations with larger cohorts are needed to characterize the UOP and to suggest more clear recommendations.

Ethics Committee Approval: The study was approved by the Ankara Numune Training and Research Hospital Ethics Committee (decision no: E-16-1065, 19 October 2016).

Informed Consent: Due to the retrospective design, patient consent was not obtained.

Peer-review: External and internal peer-reviewed.

Author Contributions: Concept - N.A., Y.H.; Design - N.A.; Supervision N.A., P.I.U.; Resources - N.A., A.Ö., ; Materials - N.A.; Data Collection and/ or Processing - N.A.; Analysis and/or Interpretation - N.A., E.K.; Literature Search - N.A.,B.Y.; Writing Manuscript - N.A.; Critical Review - N.A.

Conflict of Interest: No conflict of interest was declared by the authors.

Financial Disclosure: The authors declared that this study received no financial support.

\section{References}

1. Savin JA. How should we define itching? J Am Acad Dermatol 1998; 39: 268-9.

2. Ständer S, Weisshaar E, Mettang T, Szepietowski JC, Carstens E, Ikoma A, et al. Clinical classification of itch: a position paper of the International Forum for the Study of Itch. Acta Derm Venereol. 2007; 87: 291-4.

3. Weisshaar E, Fleischer AB Jr, Bernhard JD. Pruritus and Dysesthesia. In: Bolognia JL JJ, Schaffer JV, editors. Dermatology. 3rd ed. London: Saunders; 2012. pp.111-25.

4. Ständer S. Classification of Itch. Curr Probl Dermatol 2016; 50: 1-4.

5. Kowal P, Peachey K. Information needs for research, policy and action on ageing and older adults. A report of the follow-up meeting to the 2000 Harare MDS Workshop. World Health Organization; 2001: 1-27.

6. Weisshaar E, Szepietowski JC, Darsow U, Misery L, Wallengren J, Mettang T, et al. European guideline on chronic pruritus. Acta Derm Venereol 2012;92:56381

7. Mowad MC, Marks JG Jr. Allergic contact dermatitis. In: Bolognia JL JJ, Schaffer JV, editors. Dermatology. $3^{\text {rd }}$ ed. London: Saunders; 2012. pp. 233-48.
8. Millington GWM, Collins A, Lovell CR, Leslie TA, Yong ASW, Morgan JD, et al. British Association of Dermatologists' guidelines for the investigation and management of generalized pruritus in adults without an underlying dermatosis, 2018. Br J Dermatol 2018; 178: 34-60.

9. Alonso-Llamazares J, Rogers RS $3^{\text {rd }}$, Oursler JR, Calobrisi SD. Bullous pemphigoid presenting as generalized pruritus: observations in six patients. Int J Dermatol 1998; 37: 508-14.

10. Bolotin D, Petronic-Rosic V. Dermatitis herpetiformis. Part I. Epidemiology, pathogenesis, and clinical presentation. J Am Acad Dermatol 2011; 64: $1017-$ 24

11. Lee HG, Stull C, Yosipovitch G. Psychiatric disorders and pruritus. Clin Dermatol 2017; 35: 273-80.

12. Yonova D. Pruritus in certain internal diseases. Hippokratia. 2007; 11: 67-71.

13. Pereira MP, Kremer AE, Mettang T, Ständer S. Chronic pruritus in the absence of skin disease: pathophysiology, diagnosis and treatment. Am J Clin Dermatol 2016; 17: 337-48.

14. Altunay IK, Koslu A. Psychogenic pruritus. Turk J Dermatol 2008; 2: 116-20.

15. Signorelli MS, Cinconze M, Nasca MR, Marino M, Martinotti G, Di Giannantonio $\mathrm{M}$, et al. Can topiramate induce pruritus? A case report and review of literature. CNS Neurol Disord Drug Targets 2015; 14: 309-12.

16. Warlich B, Fritz F, Osada N, Bruland P, Stumpf A, Schneider G, et al. HealthRelated Quality of Life in Chronic Pruritus: An analysis related to disease etiology, clinical skin conditions and itch Intensity. Dermatology 2015; 231: 253-9

17. Clerc CJ, Misery L. A Literature review of senile pruritus: from diagnosis to treatment. Acta Derm Venereol 2017; 97: 433-40.

18. Kopyciok ME, Ständer HF, Osada N, Steinke S, Ständer S. Prevalence and characteristics of pruritus: A one-week cross-sectional study in a German Dermatology Practice. Acta Derm Venereol 2016; 96: 50-5.

19. Kouwenhoven TA, van de Kerkhof PCM, Kamsteeg M. Use of ora antidepressants in patients with chronic pruritus: A systematic review. J Am Acad Dermatol 2017; 77: 1068-73.

20. Zachariae R, Lei U, Haedersdal M, Zachariae C. Itch severity and quality of life in patients with pruritus: preliminary validity of a Danish adaptation of the itch severity scale. Acta Derm Venereol. 2012; 92: 508-14.

21. Jeon C, Yan D, Nakamura M, Sekhon S, Bhutani T, Berger T, et al. Frequency and management of sleep disturbance in adults with atopic dermatitis: A Systematic Review. Dermatol Ther (Heidelb) 2017; 7: 349-64.

22. Jensen P, Zachariae C, Skov L, Zachariae R. Sleep disturbance in psoriasis case-controlled study. Br J Dermatol 2018; 179: 1376-84

23. Balp MM, Khalil S, Tian H, Gabriel S, Vietri J, Zuberbier T. Burden of chronic urticaria relative to psoriasis in five European countries. J Eur Acad Dermatol Venereol 2018; 32: 282-90.

24. Pedroni MN, Hirotsu C, Porro AM, Tufik S, Andersen ML. The role of sleep in pemphigus: a review of mechanisms and perspectives. Arch Dermatol Res 2017; 309: 659-64. 